\title{
EFEKTIVITAS PELAKSANAAN E-LEARNING BAGI BASE STATION SUBSYSTEM (BSS) ENGINEER DI LINGKUNGAN PT TELKOMSEL INDONESIA
}

\author{
Agustina Hanafi \\ Program Studi Manajemen \\ Fakultas Ekonomi \\ Universitas Sriwijaya
}

\begin{abstract}
Objectives on this research is to find out sveral variables affecting effectiveness on e-learning programme conducted by PT Telkomsel Indonesia for its Base Station Subsystem Engineer. Using Computer Based Instruction approaching model from Lowe et all,2005 (A theory of effective computer-based instruction for adults) combined with integrated model of training evaluation and effectivenes from Alvarez et all, 2010, construct of his research was built. By means of those model, some hypotheses has been made: individual characteristics of learner, organizational characteristics and in the same tie those three variables causality related to e-learning effectiveness. Method used in this research is descriptive and assosiative research to describe samples behaviour wihtin research framework as well as finding out correlation among independent variables to dependent one. Using 100 BSS engineer all over Telkomsel area, results of this research proves that there are significant correlations among three variables above to $e$ learning effectiveness conducted by PT. Telkomsel Indonesia and causality of variables can be proved.
\end{abstract}

Keywords:

e-learning, training effectiveness 


\section{PENDAHULUAN}

\subsection{Latar Belakang}

Setiap organisasi tentu menyadari bahwa aspek sumber daya manusia adalah salah satu aspek terpenting yang tidak saja berperan utama dalam menjalankan dinamika organisasi, tetapi juga menentukan arah dan masa depan kehidupan organisasi tersebut. Untuk dapat berperan secara optimal, sudah selayaknya semua sumberdaya manusia mendapatkan kemampuan yang sepadan dengan tugas dan tantangan yang mereka hadapi dalam kegiatan organisasi sehari-hari untuk mengantisipasinya maka perlu sumberdaya manusinya diberi pelatihan.

Pelatihan dapat didefinisikan sebagai pengembangan seperangkat kemampuan sumberdaya manusia dalam melakukan pekerjaannya sesuai kebetuhan organisasi yang bertujuan untuk membantu pekerja melaksanakan pekerjaan yang sedang berjalan pada tingkat optimum serta untuk mengembangkan karyawan untuk pekerjaan dimasa datang, (Attwood, 2010:131).

Selanjutnya, pemilihan jenis pelatihan oleh suatu organisasi tertentu disesuaikan dengan kebutuhan serta kemampuan aspek perusahaan lain seperti ketersediaan budget yang mencukupi untuk kegiatan pelatihan serta kemampuan teknis lainnya, misalkan saja ketersediaan prasarana pelaksanaan pelatihan internal organisasi.

Secara umum, pelaksanaan pelatihan bisa dilakukan secara in-house training atau training dari pihak luar perusahaan, dalam hal ini bisa saja sumber pelatihan tersebut didapatkan dari konsultan atau pabrikan pembuat suatu perangkat lunak dan keras. Dari sisi metode, pelatihan secara umum dilaksanakan dengan tatap muka langsung antara peserta dengan trainernya, yang terutama ditujukan untuk penguasaan kemampuan teknis, apalagi jika peserta tidak saja diberikan pengenalan teoritis melainkan 
bersentuhan langsung dengan aspek-aspek

operasional, sebagaimana dalam pelatihan

teknis cara pengoperasian suatu mesin atau perangkat lunak.

Semakin majunya teknologi informasi dalam dunia kerja, maka akan sangat dimungkinkan bagi organisasi/perusahaan untuk dapat melaksanakan fungsi pelatihan secara jarak jauh, online tanpa memerlukan tatap muka langsung antara peserta pelatihan (training) dengan trainernya. Pelatihan semacam ini biasanya ditujukan sebagai pengenalan awal tanpa memasukan aspek-aspek operasional di lapangan.

PT Telekomunikasi Seluler Indonesia (Telkomsel) sebagai market leader dalam industri jasa layanan komunikasi bergerak di Indonesia sejak awal berdirinya telah konsisten menyelenggarakan pelatihan bagi seluruh karyawannya untuk mengantisipasi pertumbuhan industri ini, persaingan dengan kompetitor yang semakin ketat, serta penggunaan teknologi-teknologi baru seiring dengan tuntutan kebutuhan komunikasi yang semakin kompleks.

Sejak tahun 2005, PT Telkomsel telah mengimplementasikan suatu sistem manajemen sumberdaya manusia yang terintegrasi melalui jaringan data internal perusahaan yang disebut dengan Human Resources Information System (HRIS). Seiring dengan perkembangannya, HRIS tidak saja digunakan untuk kegiatan Human Resources Management (HRM) sehari-hari seperti absenesi, penggajian, sistem lembur serta performance apprasial, melainkan juga telah diujicobakan suatu bentuk pelatihan baru yang dilakukan secara online bagi karyawan teknik dibagian operasional Base Station Subsystem (BSS). Pelatihan tersebut meliputi pengenalan teknologi Global System for Mobile Communication (GSM), General Packet Radio Acces (GPRS), 3G \& Universal Mobile Telecommunication System 
(UMTS) Network, serta Signaling System \#7 (SS7).

Pelatihan yang merupakan kerja sama PT Telkomsel dan Nokia-Siemens Network Academy tersebut dilakukan oleh semua BSS engineer secara online dari komputer masing-masing di semua area di Indonesia dengan alokasi waktu yang fleksibel tergantung waktu luang yang dimiliki engineer bersangkutan. Setelah fase tutorial sekitar 1,5 jam plus quiz disetiap akhir bab, peserta akan diuji secara online untuk mengetahui tingkat pemahaman akan materi pelatihan yang sudah diberikan. Jika hasil tes tersebut telah melewati nilai kritis tertentu, peserta dapat dinyatakan telah lulus pelatihan dan selanjutnya sertifikat online akan dihasilkan oleh server lengkap beserta serial-number sertifikatnya.

Dalam jurnal yang diterbitkan oleh The Cape Group yang mengevaluasi implementasi e-learning di beberapa negara di kawasan Asia Tenggara ditemukan fakta bahwa hanya beberapa saja dari perusahaan di Asia Tenggara yang telah menguji cobakan dan menerapkan e-learning terutama perusahaan-perusahaan yang bergerak dalam bidang teknologi informasi telekomunikasi dan industri migas, (Sahijwani et all, 2009:2).

$$
\text { Tantangan terbesar dari }
$$
implementasi e-learning ini adalah :

a. Akses ke content e-learning yang tidak mudah bagi karyawan.

b. Content atau materi dalam e-learning itu sendiri.

c. Integrasi antara e-learning dengan sistem HR yang sudah ada.

\subsection{Perumusan Masalah}

Bertolak dari beberapa isu di atas, maka evaluasi uji coba implementasi $e$ learning dilingkungan kerja PT Telkomsel akan dibahas, yang secara umum akan dicoba digali tingkat efektifitasnya bagi 
engineer yang telah mengikuti pelatihan online tersebut.

Hasil program e-learning yang kurang signifikan ini di tandai dengan lamanya proses adaptasi dari BSS engineer dalam melakukan adaptasi terhadap beberapa perangkat baru yang terpasang, yang prinsipprinsip pengoperasian dan penanganan gangguannya termasuk dalam materi $e$ learning yang diberikan perusahaan. Oleh karenanya problem statement dalam penelitian ini adalah : apakah e-learning yang dilaksanakan PT Telkomsel bagi BSS engineer sudah cukup efektif?

Dengan mengambil sampel BSS engineer di beberapa area/regional akan dicoba menjawab beberapa pertanyaan seperti :

a. Sejauh mana faktor-faktor individu dari engineer yang mengikuti program $e$ learning mempengaruhi tingkat efektifitas pelaksanaan program.
b.Sejauh mana faktor-faktor organisasi dalam hal ini berbagai keadaan dan kebijakan perusahaan juga memberikan pengaruh pada tingkat efektifitas program e-learning yang diikuti karyawannya.

c. Sejauh mana desain materi e-learning itu sendiri juga memberikan pengaruh pada tingkat efektifitas pelaksanaan e-laerning.

\subsection{Tujuan Penelitian}

Tujuan penelitian ini adalah untuk mengetahui :

a.Signifikansi pengaruh faktor karakteristik individu pada tingkat efektifitas program e-learning.

b.Signifikansi pengaruh faktor karakteristik organisasional pada tingkat efektifitas program e-learning.

c. Signifikansi pengaruh faktor karakteristik materi e-learning pada tingkat efektifitas program e-learning. 


\subsection{Manfaat Penelitian}

Manfaat dari penelitian ini terbagi menjadi :

\section{a. Manfaat Praktis}

Hasil penelitian ini dapat dijadikan bahan masukan dalam menentukan tolak ukur tingkat efektifitas yang dihasilkan oleh program e-learning dilingkungan PT. Telkomsel dengan mengacu pada desain elearning yang telah ada, juga diharapkan mampu menjadi dasar bagi perbaikan desain pelatihan melalui e-learning bagi karyawan di lingkungan PT. Telkomsel di masa yang akan datang.

\section{b.Manfaat Teoritis}

Penelitian ini diharapkan dapat memberikan kontribusi kepada ilmu pengetahuan, khususnya mengenai manajemen sumber daya manusia dan perilaku organisasi.

\section{STUDI PUSTAKA}

\subsection{Landasan Teori}

\subsubsection{Pelatihan}

Pelatihan sebagai suatu fungsi dalam manajeman sumber daya manusia memiliki beberapa ciri yang dapat dibedakan dari pendidikan sebagai berikut (Tabel 1.).

Tabel 1.

Perbedaan antara Pendidikan dan Pelatihan

\begin{tabular}{||c||c||c||}
\hline \multicolumn{1}{|c|}{ Ciri Proses belajar } & Pendidikan & Pelatihan \\
\hline \hline Sasaran & $\begin{array}{c}\text { Sasaran yang lebih abstrak yang } \\
\text { disesuaikan dengan kebutuhan } \\
\text { perorangan dan masyarakat pada } \\
\text { umumnya }\end{array}$ & $\begin{array}{c}\text { Sasaran perilaku yang khas untuk } \\
\text { membuat karyawan lebih efektif } \\
\text { dalam pekerjaan mereka }\end{array}$ \\
\hline \hline Skala waktu & $\begin{array}{c}\text { Umumnya merupakan proses } \\
\text { jangka panjang }\end{array}$ & $\begin{array}{c}\text { Dapat berjangka sangat pendek, } \\
\text { terutama jika menyangkut } \\
\text { perolehan keterampilan khusus }\end{array}$ \\
\hline \hline Isi & Isi digambarkan secara luas & $\begin{array}{c}\text { Seringkali isinya agak terbatas } \\
\text { yang disesuaikan dengan keadaan } \\
\text { kerja karyawan }\end{array}$ \\
\hline \hline
\end{tabular}


Beberapa faktor dalam organisasi jenis/gaya pelatihan serta fungsi manajemen yag mempengaruhi kebijakan dan proses sumber daya lainnya, (Mondy, 2008 :167). pelatihan \& pengembangan antara lain Suatu model desain dan proses bagaimana adalah dukungan manajemen puncak, proses pelatihan berlangsung di dalam suatu komitmen para manajer lini, perkembangan organisasi dapat dilihat pada Gambar 1 . teknologi, kompleksitas suatu organisasi, berikut:

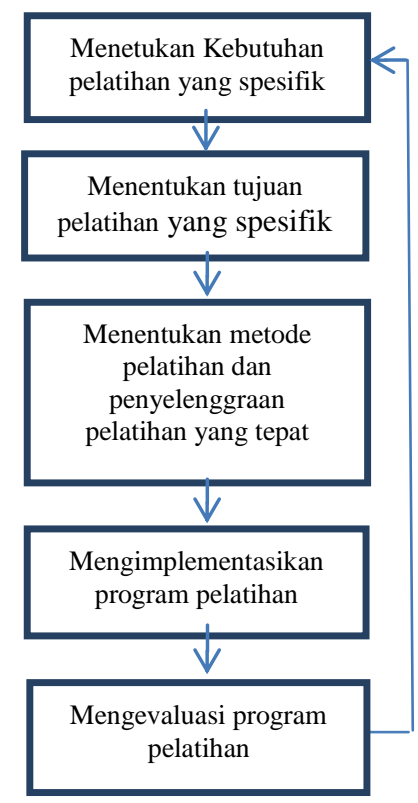

Gambar 1.

Model pelatihan dalam organisasi

\subsubsection{Desain Pelatihan}

Desain suatu pelatihan didefinisikan sebagai suatu kegiatan pembuatan rencana pelatihan bagi karyawan dengan pendekatan yang sistematik dan strategik sehingga mampu dicapai suatu kondisi kinerja optimal bagi karyawan dan juga bagi perusahaan sebagai keluaran dari proses pelatihan yang akan dibuat.

(Dimmock.2004: 390) mengemukakan bahwa pelatihan dapat membantu dalam penggunaan seumberdaya 
perusahaan secara lebih efektif hanya jika didekati secara bersistem, (Attwood, 2010:134). Proses desain pelatihan selanjutnya didefinisikan sebagai urutan kegiatan 5 tahap :

a. Menentukan rencana perusahaan

b.Mengindentifikasi kebutuhan akan pelatihan dan pengembangan rencana pelatihan (langkah $1 \& 2$ disebut tahap 1)

c. Merencanakan program pelatihan (tahap 2)

d.Melaksanakan program pelatihan (tahap 3)

e. Menilai program pelatihan ( tahap 4 )

\subsubsection{Analisis Kebutuhan Pelatihan}

Dalam melakukan tahap penilaian kebutuhan pelatihan diperlukan tiga jenis analisis. Ketiga jenis analisis penilaian kebutuhan pelatihan tersebut adalah :

a. Analisis organisasional

Analisis organisasional merupakan pemeriksaan jenis jenis permasalahan yang terjadi dalam organisasi. Analisis organisasi dilakukan untuk mengetahui di departemen atau level mana sebaiknya dilakukan pelatihan. dan pengembangan.

b. Analisis operasional

Analisis operasional adalah proses untuk menentukan perilaku yang dituntut berdasarkan standar-standar pekerjaan yang harus dipenuhi seorang karyawan agar mampu melaksanakan pekerjaan dan mencapai kinerja yang diharapkan.

c. Analisis individual

Analisis individu mengidentifikasi kesenjangan antara kebutuhan kerja dan organisasi dengan karakteristik dari masing masing karyawan. Kebutuhan individu adalah perbedaan antar kinerja yang diharapkan dengan kinerja yang sesungguhnya.

\subsubsection{Pelatihan Berbasis Komputer} secara Online

Dari sekian banyak jenis pelatihan sumber daya manusisa yang dapat dilakukan didalam lingkungan perusahaan, terdapat 
satu jenis pelatihan yang menggunakan media komunikasi elektronik berbasis komputer. Pelatihan jenis ini dinamakan Computer Based Instruction Training atau CBI Training. Dalam perkembangannya, jenis pelatihan seperti ini sering disebut sebagai E-Learning karena proses pelatihan menggunakan media jaringan elektronik berbasis internet.

\section{E-Learning didefinisikan sebagai} suatu sistem penyelenggaraan pelatihan menggunakan instruksi jarak jauh secara online, (Mondy, 2008:174). Kelebihan yang dimiliki pelatihan jenis ini adalah adanya fleksibilitas yang tinggi bagi peserta pelatihan dalam memilih waktu serta melaksanakan proses pelatihannya tahap demi tahap sesuai kemampuannya. Saat ini E-Learning semakin diminati oleh banyak organisasi karena mampu menawarkan biaya yang lebih murah dibandingkan pelatihan konvensional dalam kelas. Selain itu, dengan semakin kompetitifnya dunia kerja saat ini dimana tingkat turn over karyawan semakin tinggi, maka pelatihan konvensional semakin tidak menarik. Karakteristik dasar dari $E$ Learning adalah penggunaan instruksi berbasis komputer secara online, metode penyajian yang terstruktur dengan jelas, serta adanya kemampuan umpan balik untuk evaluasi peserta pelatihan Evaluasi pelaksanaan pelatihan.

\subsubsection{Evaluasi Pelatihan}

Evaluasi pelatihan didefinisikan sebagai suatu upaya untuk mengukur kesesuaian hasil menentukan nilai suatu pelatihan bagi organisasi, (Mondy,2008:183). Model yang sering dipakai untuk mengevaluasi pelaksanaan suatu program pelatihan adalah model Kirkpatrick yang komponennya terdiri dari : opini peserta pelatihan, materi pelatihan, perubahaan perilaku peserta ( transfer hasil pelatihan pada kualitas hasil pekerjaan ) serta kesesuaian dengan tujuan pelatihan yang 
telah ditentukan ( pengaruh pada kinerja) Pelatihan dengan tujuan yang telah ditetapkan di awal pelatihan. Setidaknya ada tiga alasan utama mengapa suatu pelatihan harus dievaluasi, diantaranya adalah untuk menentukan apakah suatu program pelatihan perlu dilanjutkan atau tidak, apakah pelatihan perlu dimodifikasi dan dikembangkan.

\subsubsection{Efektifitas Pelaksanaan $E$ -}

\section{Learning}

Sesungguhnya saat ini masih belum banyak penelitian yang membahas efektifitas dari E-Learning karena terdapat dua efektifitas pelaksanaan e-learning. Para ahli perilaku mendekati efektifitas dari pengkondisian lingkungan pelatihan yang mampu merangsang peserta untuk menampilkan sejumlah perilaku yang mendukung efektifitas. Sebaliknya, para konstruktifis mendekati efektifitas dari bagaimana proses e-learning dilakukan. Williams, menyarankan adanya integrasi dari kedua pendekataan diatas untuk mengukur tingkat efektifitas e-learning, (Williams, 2000: 3).

Lowe et all (2005: 164) menyajikan suatu model pendekatan pengurukuran suatu proses CBI seperti pada gambar 2. berikut: pendekatan berbeda untuk mengukur

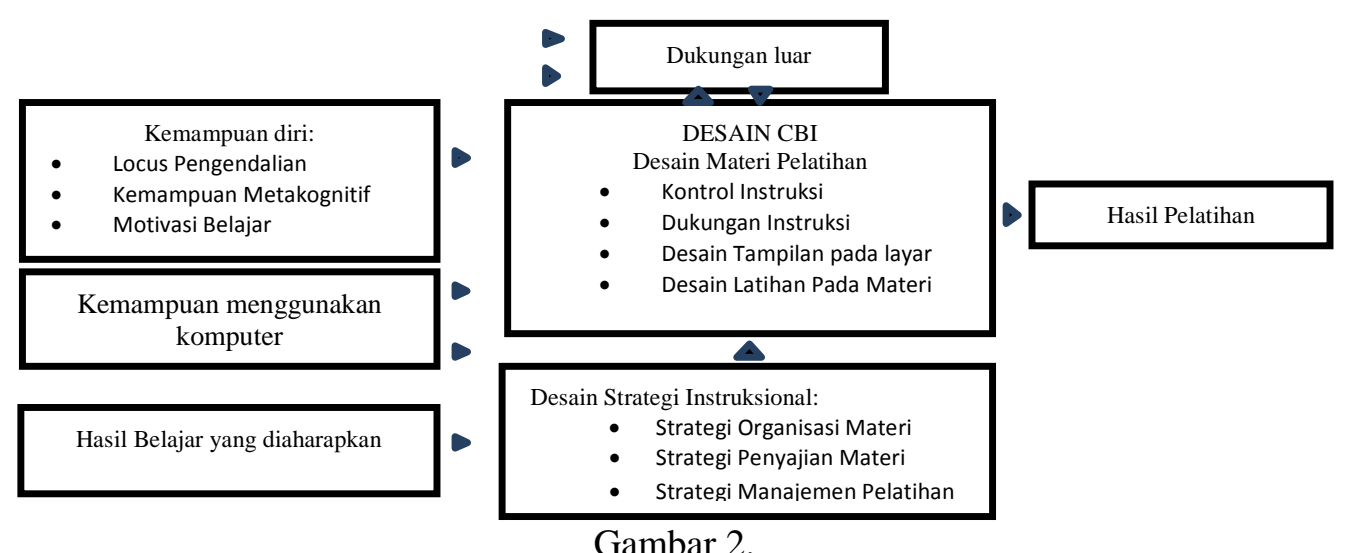

Model Pendekatan Pengukuran Suatu Proses CBI 
Model pelatihan berbasis komputer dari Holton menggambarkan suatu system pelatihan sebagai suatu proses yang memiliki input berupa karakteristik individual dari peserta pelatihan yang digambarkan memiliki sejumlah atribut seperti kemauan diri, kemampuan menggunakan komputer dan hasil pelatihan yang ia harapkan sebelumnya. Faktor-faktor diluar diri peserta dimasukkan kedalam bagian proses yang digambarkan sebagai dukungan organisasi pada individu sekaligus pada pembuatan desain pelatihan yang sesuai bagi individu tersebut. Faktor organisasional ini bersamasama dengan desain e-learning membentuk proses yang akan melakukan transformasi pada input yang akhirnya menghasilkan output berupa hasil pelatihan. Proses pada model Holton secara umum merupakan gambaran dari bagaimana suatu materi $e$ learning mulai ditawarkan oleh organisasi kepada para karyawannya, proses pemilihan e-learning oleh karyawan yang bersangkutan, proses enroll, log-on, proses selama pelatihan hingga meliputi isi (content) e-learning yang disajikan pada peserta yang merupakan proses desain materi hingga cara materi tersebut disajikan di layar komputer. Dukungan luar (external support) dalam model diatas didefinisikan sebagai dukungan dari organisasi seputar teknis pelaksanaan program seperti dukungan dari sistem manajemen sumber daya manusia yang ada, penyediaan perangkat keras komputer, serta bantuan sesama karyawan.

\subsection{Penelitian Terdahulu}

Berikut adalah penelitian-penelitian terdahulu yang pernah dilakukan :

a. Studi mengenai efektifitas suatu pelatihan meliputi kajian terhadap semua karakteristik individu, organisasi dan pelatihan itu sendiri yang memberikan pengaruh sebelum pelatihan dilaksanakan, ketika pelatihan dilaksanakan dan sesudah pelatihan, (Alvarez et all, 2010: 387). 
Dalam jurnal tersebut disebutkan bahwa hampir semua literature sumber daya manusia menunjukkan bahwa efektifitas suatu pelatihan didefiniskan sebagai :

- Kinerja pembelajaran (learning performance)

- Hasil/transfer pengetahuan (transfer performance)

Selanjutnya, penulis juga menggunakan definisi ini untuk mengukur efektifitas pelakasanaan program e-learning.

b.Keefektifan E-Learning Sebagai Media Pembelajaran (Studi Evaluasi Model Pembelajaran E- Learning SMK Telkom Sandhy Putra Purwokerto) (Hanum,2013:90). Hasil penelitiannya menyimpulkan bahwa: a). Aspek perencanaan pembelajaran e-learning termasuk dalam kategori cukup efektif $(77,5 \%) ;$ b). Aspek perancangan dan pembuatan materi menujukkan kategori cukup efektif $(75,14 \%) ; \quad$ c). Aspek penyampaian atau pembelajaran e-lerning tingkat kecenderungan cukup efektif $(75 \%) ;$ d). Aspek interaksi pembelajaran cukup efektif $(66,1 \%)$ dan e). Aspek evaluasi pelaksanaan pembelajaran $e$ learning cukup efektif $(69,01 \%)$.

c.Efektifitas Penerapan E-Learning Model Edmodo dalam Pembelajaran Pendidikan Agama Islam terhadap Hasil Belajar Siswa (Studi Kasus: SMK Muhammadiyah I Sukoharjo) (Nu'man 2014:1-14). Hasil analisis dan pembahasan dapat disimpulkan bahwa efektivitas penggunaan media pembelajaran e-learning berbasis edmodo lebih tinggi daripada menggunakan media pembelajaran konvensional, hal ini ditunjukkan hasil hipotesis posttest dengan uji $\mathrm{t}$ adalah $\mathrm{P}$ $(0,699)<$ oc $(0,05)$.

d.Pengaruh penggunaan E-Learning terhadap Motivasi dan Efektifitas Pembelajaran Fisika Bagi Siswa SMA (Studi Kasus Di SMA Negeri I Depok) ( Hidayat, 2011: 886). Hasil Penelitian ini 
dapat disimpulkan bahwa peningkatan motivasi dan efektifitas belajar secara signifikan ditemukan pada siswa yang menggunakan e-learning dibandingkan dengan cara konvensional dalam proses pembelajaran.

Dengan menggabungkan konsep dan metode penelitian yang dilakukan oleh The
Cape Group serta model pengukuran output dari suatu pelatihan berbasis computer serta defines efektifitas oleh para peneliti terdahulu , maka penulis membuat suatu model hibrida untuk pengukuran efektifitas pelaksanaan e-learning di lingkungan PT. Telkomsel yang dapat dilihat pada Gambar 3. di bawah ini :

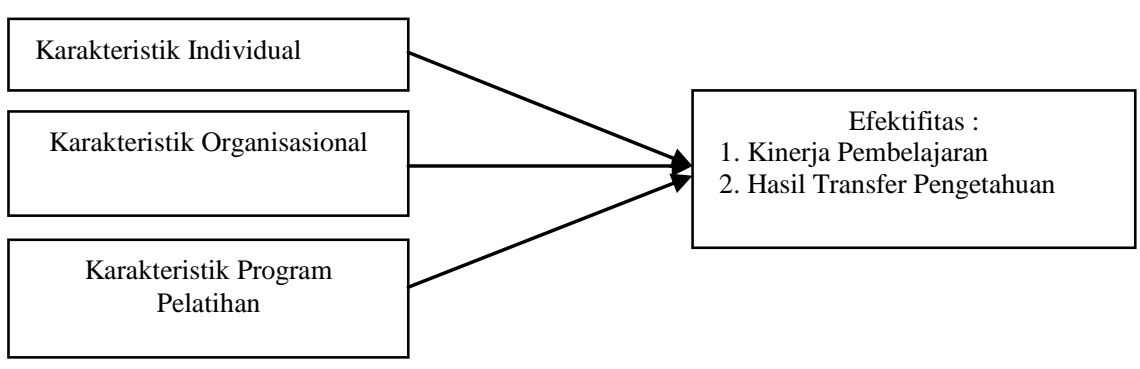

Gambar 3.

Model pengukuran efektifitas e-learning di PT Telkomsel

\subsection{Kerangka Konseptual Penelitian}

Berikut adalah kerangka konseptual dari penelitian yang dilakukan (Gambar 4.).

\subsection{Hipotesis Penelitian}

Menurut salah satu pakar (Sugiyono,2008:93) hipotesis adalah : “jawaban sementara terhadap rumusan masalah penelitian, dikatakan sementara, karena jawaban yang diberikan baru didasarkan pada teori yang relevan, belum didasarkan pada fakta-fakta empiris yang diperoleh melalui pengumpulan data”. Maka pada penelitian ini diajukan hipotesis sebagai berikut :

a. Ada pengaruh positif dan signifikan karakteristik individual terhadap efektifitas pembelajaran e-learning. 


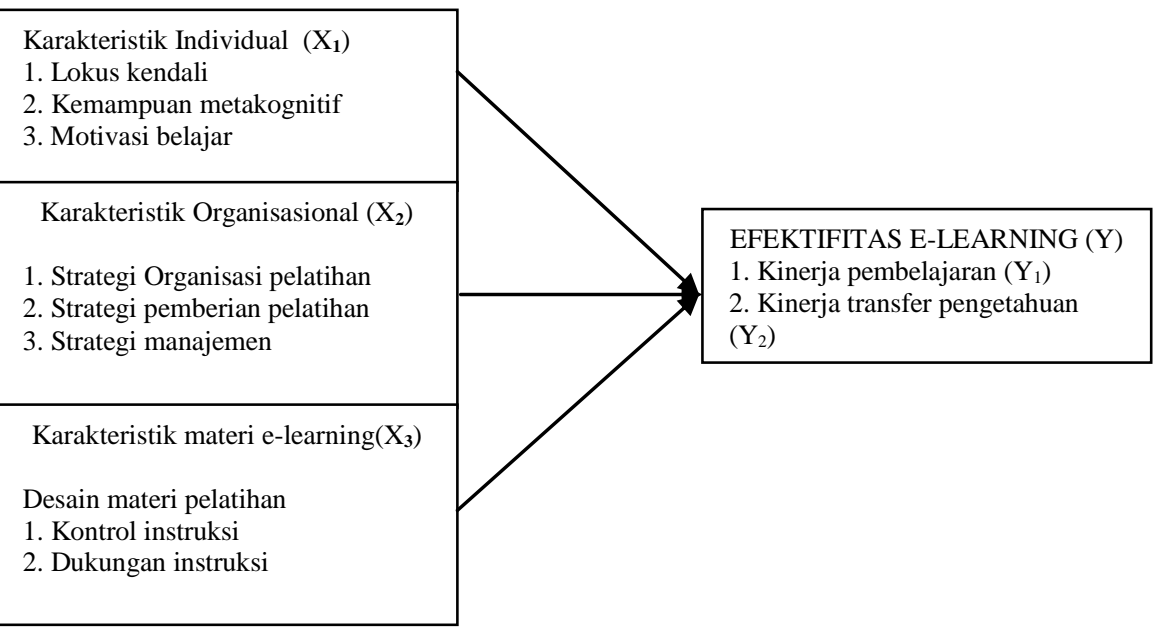

Gambar 4.

Kerangka Konseptual Penelitian

b. Ada pengaruh positif dan signifikan dan selanjutnya tingkat saling karakteristik organisasional terhadap keterkaintannya.

efektifitas pembelajaran e-learning.

c. Ada pengaruh positif dan signifikan

karakteristik materi e-learning terhadap

efektifitas pembelajaran e-learning.

\section{METODE PENELITIAN}

Penelitian ini menggunakan metode riset deskriptif dan riset asosiatif, dengan demikian desain yang digunakan adalah kausalitas dimana akan dicari kandungan sebab akibat dari variabel bebas dan terikat

\subsection{Populasi, Sampel, Besar Sampel dan Teknik Pengambilan Sampel}

Dari sekitar 1000 orang BSS engineer yang ada diseluruh wilayah kerja PT. Telkomsel maka diambil sampel sebanyak 100 orang dari seluruh populasi BSS engineer di lingkungan kerja PT. Telkomsel yang dipilih secara acak, diman semua responden memiliki kesempatan yang sama untuk dipilih sebagai sampel. Penetuan jumlah sampel ini didasarkan atas jumlah 
variabel bebas yang digunakan dalam

penelitian ini yaitu sebanyak 3 variabel,

sehingga jumlah sampel sebanyak minimal

25 kali jumlah variabel bebasnya adalah 75

(Augusty, 2006:45)

\subsection{Definisi Operasional variabel}

Berikut pada Tabel 2. dijelaskan

definisi operasional variabel.

Tabel 2.

Definisi Operasional Variabel

\begin{tabular}{|c|c|c|}
\hline Variabel & Dimensi & Indikator \\
\hline $\begin{array}{c}\text { Karakteristik } \\
\text { Individual }\left(\mathrm{X}_{1}\right)\end{array}$ & Kontrol Individu & $\begin{array}{ll} & \text { Lokus kendali; penentu nasib mereka sendiri } \\
\text { - } & \text { Kemampuan metakognitif, kemampuan menggunakan } \\
& \text { komputer } \\
\text { - } & \text { Motivasi belajar, tingkat hasil belajar yang diinginkan } \\
\end{array}$ \\
\hline $\begin{array}{l}\text { Karakteristik } \\
\text { Organisasional } \\
\qquad\left(\mathrm{X}_{2}\right)\end{array}$ & $\begin{array}{l}\text { Desain strategi } \\
\text { instruksional }\end{array}$ & $\begin{array}{ll}\text { - } & \text { Strategi organisasi pelatihan } \\
\text { - } & \text { Strategi pemberian pelatihan } \\
\text { - } & \text { Strategi manajemen pelatihan }\end{array}$ \\
\hline $\begin{array}{l}\text { Karakteristik } \\
\text { Materi e- } \\
\text { learning }\left(\mathrm{X}_{3}\right) \\
\end{array}$ & Desain materi pelatihan & $\begin{array}{ll}- & \text { Kontrol instruksi } \\
\text { - } & \text { Desain tampilan pada layar } \\
\text { - } & \text { Desain latihan pada materi } \\
\end{array}$ \\
\hline $\begin{array}{l}\text { Efektifitas e- } \\
\text { learning (Y) }\end{array}$ & $\begin{array}{l}\text { 1. Kinerja pembelajaran } \\
\text { 2. Kinerja transfer } \\
\text { pengetahuan }\end{array}$ & $\begin{array}{ll}\text { - } & \text { Pelaksanaan tugas yang dicapai dengan menggunakan } \\
\text { kemampuan } \\
\text { - Kemampuan berinovasi dan kemampuan mentransfer } \\
\text { materi kepada peserta }\end{array}$ \\
\hline
\end{tabular}

\subsection{Instrumen Penelitian}

Instrumen yang digunakan dalam

mengukur variabel penelitian ini yaitu

kuesioner sedangkan skala instrumen yang

digunakan adalah skala Likert.

\subsection{Jenis dan Sumber Data}

Data yang digunakan terbagi

menjadi berikut ini :

a. Data Primer

Dalam penelitian ini, sumber data primer

diperoleh melalui penyebaran kuesioner

kepada responden Base Station Subsystem

(BSS) Engineer PT Telkomsel Indonesia. 
b.Data Sekunder

Dalam penelitian ini, sumber data sekunder adalah literatur buku dan situs internet. Data sekunder ini diperlukan dengan maksud mendukung kebenaran data primer.

\subsection{Metode Pengumpulan Data}

Data dalam penelitian ini dikumpulkan dengan menggunakan metode survei, yaitu dengan menyebarkan kuesioner pada sampel yang akan diteliti. Metode pengumpulan data dilakukan dengan self administered survey di mana responden diminta untuk mengisi sendiri kuesioner yang diberikan. Pengumpulan data ini dilakukan dengan menyebarkan kuesioner secara manual yaitu dengan bertemu langsung dengan responden, maupun kuesioner online.

\subsection{Teknik Analisis Data}

Analisis data menyeluruh dan hasil penelitian ini dilakukan menggunakan alat uji statistik yang diperoleh dari program komputer Statistical Package for Social Sciences (SPSS) for Windows versi 21.00 melalui:

a. Analisis Deskriptif

b. Analisis Regresi

- Analisis Regresi Linear Berganda

- Analisis Regresi Moderat (Moderated Regression Analysis)

c. Uji Hipotesis

\section{HASIL DAN PEMBAHASAN}

\subsection{Uji Instrumen}

\subsubsection{Uji Validitas}

Berikut pada Tabel 3. disajikan hasil uji validitas data. 
Tabel 3.

Uji Validitas Data

\begin{tabular}{|c|c|c|c|}
\hline Variabel & $\begin{array}{c}\text { No } \\
\text { Pernyataan } \\
\end{array}$ & $\begin{array}{c}\text { Kooefesien } \\
\text { korelasi }\end{array}$ & Keterangan \\
\hline \multirow[t]{11}{*}{ Karakteristik Individual $\left(\mathbf{X}_{1}\right)$} & 1 & 0.46 & Valid \\
\hline & 2 & 0.923 & Valid \\
\hline & 3 & 0.532 & Valid \\
\hline & 4 & 0.541 & Valid \\
\hline & 5 & 0.239 & Tidak Valid \\
\hline & 6 & 0.421 & Valid \\
\hline & 7 & 0.780 & Valid \\
\hline & 8 & 0.642 & Valid \\
\hline & 9 & 0.675 & Valid \\
\hline & 10 & 0.683 & Valid \\
\hline & 11 & 0.53 & Valid \\
\hline \multirow[t]{11}{*}{ Karakteristik Organisasional $\left(\mathbf{X}_{2}\right)$} & 1 & 0.112 & Valid \\
\hline & 2 & 0.760 & Valid \\
\hline & 3 & 0.428 & Valid \\
\hline & 4 & 0.623 & Valid \\
\hline & 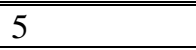 & 0.142 & Tidak Valid \\
\hline & 6 & 0.583 & Valid \\
\hline & 7 & 0.609 & Valid \\
\hline & 8 & 0.530 & Valid \\
\hline & 9 & 0.482 & Valid \\
\hline & 10 & 0.318 & Valid \\
\hline & 11 & 0.635 & Valid \\
\hline \multirow[t]{8}{*}{ Karakteristik Materi $e$-learning $\left(\mathrm{X}_{3}\right)$} & 1 & 0.865 & Valid \\
\hline & 2 & 0.770 & Valid \\
\hline & 3 & 0.902 & Valid \\
\hline & 4 & 0.824 & Valid \\
\hline & 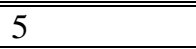 & 0.930 & Valid \\
\hline & 6 & 0.941 & Valid \\
\hline & 7 & 0.893 & Valid \\
\hline & 8 & 0.892 & Valid \\
\hline \multirow[t]{8}{*}{ Efektifitas $e$-learning $(\mathrm{Y})$} & 1 & 0.750 & Valid \\
\hline & 2 & 0.853 & Valid \\
\hline & 3 & 0.778 & Valid \\
\hline & 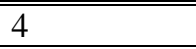 & 0.866 & Valid \\
\hline & 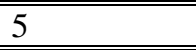 & 0.912 & Valid \\
\hline & 6 & 0.826 & Valid \\
\hline & 7 & 0.905 & Valid \\
\hline & 8 & 0.818 & Valid \\
\hline
\end{tabular}




\subsubsection{Uji Validitas Konstruk}

Uji validitas ini dilakukan untuk mengetahui pernyataan mana saja yang valid pada setiap variable yang digunakan dalam penelitian ini.Pengertian valid di sini adalah bahwa suatu pernyata an dapa digunakan untuk membentuk konstruk indikator yang dinyatakan dalam angket. Bila korelasi tiap pernyataan tersebut positif dan besarnya 0.3 ke atas maka pernyataan tersebut merupakan konstruk yang kuat, (Sugiono,2007 : 178).

Uji validitas dilakukan dengan mencari koefisien kolerasi Pearson antara skor tiap pernyataan terhadap total skor semua pernyataan untuk masing- masing responden.(Suryani dkk. 2015:326).

\subsubsection{Uji korelasi Pearson}

Pada uji korelasi Pearson, didapatkan beberapa kesimpulan sebagai berikut :

a. Karakteristik individual $\left(x_{1}\right)$ memiliki kolerasi yang signifikan terhadap kinerja pembelajaran $\left(y_{1}\right)$ dengan tingkat korelasi sebesar 0.483 dan tingkat signifikan hampir mendekati 0 .

b. Karakteristik organisasional $\left(\mathrm{x}_{2}\right)$ memiliki kolerasi yang signifikan terhadap pembelajaran $\left(y_{1}\right)$ dengan tingkat kolerasi sebesar 0.689 dan tingkat signifikan hampir mendekati 0 .

c. Karakteristik materi e-learning $\left(x_{1}\right)$ memiliki korelasi yang signifikan terhadap kinerja pembelajaran $\left(y_{1}\right)$ dengan tingkat kolerasi sebesa 0.961 ; tingkat signifikan hampir mendakati 0 .

d.Karateristik individual $\left(x_{1}\right)$ memiliki kolerasi signifikan terhadap kinerja tranfers pengetahuan $\left(y_{2}\right)$ dengan tingkat kolerasi sebesar 0.651 dan tingkat signifikan hampir mendekati 0.

e. Karateristik organisasional $\left(x_{2}\right)$ memiliki kolerasi signifikan terhadap kinerja tranfers pengetahuan $\left(y_{2}\right)$ dengan tingkat kolerasi sebesar 0.766 ; tingkat signifikan mendekati hampir 0 . 
f. Karateristik materi e-learing $\left(x_{1}\right)$ memiliki kolerasi signifikan terhadap kinerja tranfers pengetahuan $\left(y_{2}\right)$ dengan tingkat kolerasi sebesar 0.926 ; tingkat signifikan mendeekati hampir 0 .

\subsection{Uji Realibilitas}

Uji reabilitas instrument penelitian dilakukan secara internal dengan tujuan untuk mengetahui konsistensi jawan responden terhadap reabilitas dalam peneliotian ini dilakukan secara internal. Dilakukan dengan cara mengujicobakan instrument sekali saja kemudian data yangf diperoleh dianalisisa dengan teknik belah dua (split half) spearman Brown.

Teknik belah dua spearman Brown dilakukan dengan memilah jawaban responden terhadap pernyataan butir ganjil dengan genap untuk tiap variable bebas dan terikat.untuk kemudian dijumlahkan sehingga dihasilkan total nilai jawaban semua pernytaan ganjil dan genap untuk tiap responden.

$$
\text { Hasil pengelolahn SPSS }
$$

menunjukkan korelasi spearman Brown untuk butir ganjil dan genap sebesar 0.956 $(0.956>0.3)$ yang artinya insturmen penelitian cukup konsisten dan dapat digunakan untuk membentuk konstruk penelitian.

\subsection{Statistik Deskriptif}

Karakteristik Jawaban Responden

Berdasarkan pada distribusi jawaban responden pada pernyataan-pernyataan dalam angket dapat dibuat indeks dari masing-masing variabel yang diteliti. Perhitungan angka indeks ini bertujuan untuk mengetahui deskriptif kualitas dari masingmasing variabel pada sampel penelitian, apakah termasuk rendah, sedang atau kuat.

Perhitungan angka indeks dilakukan dengan teknik scoring dengan nilai maksimum adalah 5 dan minimum 1 , sesuai 
Efektivitas Pelaksanaan E-Learning... (Agustina Hanafi)

dengan skor yang digunakan dalam angket

Nilai index $=[(\% F 1 \times 1)+(\% F 2 \times 2)+$ dengan menggunakan rumus sebagai berikut:

$$
(\% F 3 \times 3)+(\% F 4 \times 4)+(\% F 5 \times 5)] / 5
$$

Tabel 4.

Indeks Karakteristik Individual Responden

\begin{tabular}{|c|c|c|c|c|c|c|}
\hline \multirow[b]{2}{*}{ Pernyataan X1 } & \multicolumn{5}{|c|}{ Frekuensi tiap skor $(\%)$} & \multirow{2}{*}{$\begin{array}{l}\text { Nilai } \\
\text { Index }\end{array}$} \\
\hline & $5(\mathrm{SS})$ & $\begin{array}{c}4 \\
(\mathrm{~S}) \\
\end{array}$ & $\begin{array}{c}3 \\
(\mathrm{R}) \\
\end{array}$ & $\begin{array}{c}2 \\
(\mathrm{TS}) \\
\end{array}$ & 1 (STS) & \\
\hline Pernyataan 1 & 59 & 41 & 0 & 0 & 0 & 91.80 \\
\hline Pernyataan 2 & 75 & 21 & 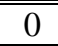 & 4 & 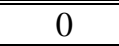 & 93.40 \\
\hline Pernyataan 3 & 24 & 73 & 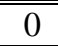 & 3 & 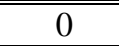 & 83.60 \\
\hline Pernyataan 4 & 24 & 73 & 0 & 3 & 0 & 83.60 \\
\hline Pernyataan 5 & 2 & 59 & 0 & 37 & 2 & 64.40 \\
\hline Pernyataan 6 & 58 & 40 & 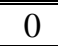 & 1 & 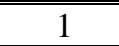 & 90.60 \\
\hline Pernyataan 7 & $\overline{51}$ & 39 & 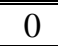 & 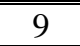 & 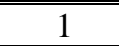 & 86.00 \\
\hline Pernyataan 8 & 22 & 67 & 0 & 10 & 1 & 79.80 \\
\hline Pernyataan 9 & 90 & 10 & 0 & 0 & 0 & 98.00 \\
\hline Pernyataan 10 & 87 & 13 & 0 & 0 & 0 & 97.40 \\
\hline Pernyataan 11 & 64 & 32 & 0 & 4 & 0 & 91.20 \\
\hline TOTAL & & & & & & 959.80 \\
\hline $\begin{array}{l}\text { Nilai Index total } \\
\text { rata-rata }\end{array}$ & & & & & & 87.25 \\
\hline
\end{tabular}

Menurut pendapat salah satu ahli menginterprestasikan dari hasil deskriptif kualitatif (Riduan,2010:22) bahwa hasil setiap item kuesioner masing-masing persentase diinterpretasikan dengan kriteria variabel dan dimensi. Berikut pada Tabel 5. dan kriteria tersebut digunakan untuk disajikan rentang skor penilaian.

Tabel 5.

Rentang score

\begin{tabular}{|l|l|}
\hline \multicolumn{1}{|c|}{ Kriteria Penilaian } & \multicolumn{1}{|c|}{ Skor Penilaian } \\
\hline \hline Sangat Tidak Setuju & $0 \%-20 \%$ \\
\hline \hline Tidak Setuju & $21 \%-40 \%$ \\
\hline \hline Cukup Setuju & $41 \%-60 \%$ \\
\hline \hline Setuju & $61 \%-80 \%$ \\
\hline \hline Sangat Setuju & $81 \%-100 \%$ \\
\hline
\end{tabular}

Nilai indeks terendah dihasilkan jika yang menghasilkan indeks $=20$ sedangkan semua responden menjawab STS $($ skor $=1)$ indeks tertinggi dihasilkan jika semua 
responden menjawab SS (skor =5) yang menghaasilkan indeks $=100$. Maka rentang indeks karakteristik individual adalah 20 hingga 100 dengan rentang sebesar 80 dengan menggunakan kriteria tiga kotak seperti yang dikemukakan (Riduan, 2010:22)

Terlihat dari tabel 4. bahwa indeks rata-rata karateristik individual responden berada pada kisaran tinggi $(87,25 \%)$, indeks tertingggi terdapat pada pernyataan nomor 9 berupa konfirmasi bahwa responden memiliki kemampuan menggunakan computer yang mendukung pelaksanaan $e$ learning, tinggginya angka indeks ini memberikan gambaran rata-rata BSS engineer di PT Telkomsel memang sudah memiliki keterampilan dasar dalam bidang teknologi komunikasi yang merupakan faktor pendukung bagi program e-learning yang diberikan perusahaan. Sedangkan indeks terendah terdapat pada pertanyaan nomor 5 yang mengkorfirmasi apakah responden pernah mendapatkan pelatihan jenis serupa. Rendahnya angka indeks ini menunjukan bahwa memang program $e$ learning ini baru diujicobakan pada BSS engineer oleh menejemen perusahaan dengan tujuan agar updet pengetahuaan dapat dilakukan secara terus menerus pada cost yang rendah. Pada pengembangan model regresi multivariate, pertanyaan ini akan dibuang dan model penelitian karena dianggap kurang mewakili konstruk yang dibuat. 
Tabel 6.

Indeks Karateristik Organisasional Responden

\begin{tabular}{|c|c|c|c|c|c|c|}
\hline \multirow[b]{2}{*}{ Pernyataan $\mathrm{X}_{2}$} & \multicolumn{5}{|c|}{ Frekuensi tiap skor $(\%)$} & \multirow[b]{2}{*}{ Nilai Index } \\
\hline & $\begin{array}{c}5 \\
(\mathrm{SS})\end{array}$ & $4(\mathrm{~S})$ & $\begin{array}{c}3 \\
(\mathrm{R}) \\
\end{array}$ & $\begin{array}{c}2 \\
(\mathrm{TS})\end{array}$ & 1 (STS) & \\
\hline Pernyataan 1 & 4 & 95 & 0 & 1 & 0 & 80.40 \\
\hline Pernyataan 2 & 33 & 67 & 0 & 0 & 0 & 86.60 \\
\hline Pernyataan 3 & 55 & 20 & 0 & 25 & 0 & 81.00 \\
\hline Pernyataan 4 & 1 & 54 & 0 & 38 & 7 & 60.80 \\
\hline Pernyataan 5 & 0 & 3 & 0 & 79 & 18 & 37.60 \\
\hline Pernyataan 6 & 66 & 33 & 0 & 1 & 0 & 92.80 \\
\hline Pernyataan 7 & 65 & 31 & 0 & 4 & 0 & 91.40 \\
\hline Pernyataan 8 & 0 & 64 & 0 & 32 & 4 & 64.80 \\
\hline Pernyataan 9 & 61 & 39 & 0 & 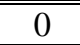 & 0 & 92.20 \\
\hline Pernyataan 10 & 22 & 71 & 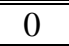 & $\bar{~} 6$ & 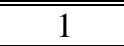 & 81.40 \\
\hline Pernyataan 11 & 55 & 44 & 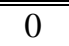 & 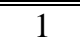 & 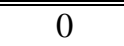 & 990.60 \\
\hline TOTAL & & & & & & 859.60 \\
\hline $\begin{array}{l}\text { Nilai Index } \\
\text { total rata-rata }\end{array}$ & & & & & & 78.15 \\
\hline
\end{tabular}

Terlihat dari tabel 6. bahwa indeks

rata-rata karateristik individual responden

berada pada kisaran tinggi $(78,15 \%)$. Angka

indeks tertinggi terdapat pada pernyataan

nomor 6 berupa konfirmasi apakah

perusahaan pelaksaan program e-learning

berupah computer dan jaringan data yang

handal tingginya angka indeks ini

menunjukan bahwa secara organisasional PT

telkomsel sebenarnya telah memiliki

prasyarat pendukung program e-learning

dari sisi infra struktur teknologinya kuat tidaknya kolerasi antara variable organisasional terhadap efektifitas $e$-learning selanjutnya akan banyak dipengaruhi oleh strategi delivery dari program itu oleh menajemen kepada BSS engineer-nya. Indeks terendah didapatkan pada pernyataan nomor 5 berupa konfirmasi akan adanya sanksi dari perusahaan pada BSS engineer yang tidak mengikuti program ini. Dimasukkannya pernyataan ini dimaksudkan untuk mengukur sejauhmana komitmen manajemen perusahaan dalam pelaksaan 
program pelatihan regular (in-house) yang memberikan sanksi apabila seorang karyawan mangkir dari pelatihan yang sudah terjadwal. Rendahnya angka indeks dan kenyataan bahwa program ini masih dalam tahap uji coba membuat pernyataan ini selanjutnya akan dibuang dari konstruk penelitian untuk variabel organisasional.

Tabel 7.

Indeks Karakteristik Materi e-learning Responden

\begin{tabular}{|c|c|c|c|c|c|c|}
\hline \multirow[b]{2}{*}{ Pernyataan $X_{3}$} & \multicolumn{5}{|c|}{ Frekuensi tiap skor (\%) } & \multirow[b]{2}{*}{ Nilai index } \\
\hline & $\begin{array}{c}5 \\
(\mathrm{SS})\end{array}$ & $4(\mathrm{~S})$ & $3(\mathrm{R})$ & 2 (TS) & 1 (STS) & \\
\hline Pernyataan 1 & 30 & 40 & 0 & 28 & 2 & 73.60 \\
\hline Pernyataan 2 & 31 & 64 & 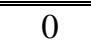 & 4 & 1 & 84.00 \\
\hline Pernyataan 3 & 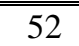 & 42 & 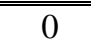 & 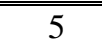 & 1 & 87.80 \\
\hline Pernyataan 4 & 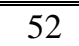 & 24 & 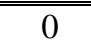 & 2 & 22 & 76.40 \\
\hline Pernyataan 5 & 54 & 42 & 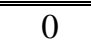 & 3 & 1 & 89.00 \\
\hline Pernyataan 6 & 54 & 43 & 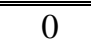 & 2 & 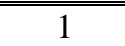 & 89.40 \\
\hline Pernyataan 7 & 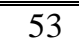 & 40 & 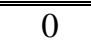 & 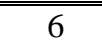 & 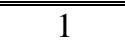 & 87.60 \\
\hline Pernyataan 8 & 53 & 41 & 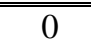 & 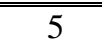 & 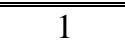 & 88.00 \\
\hline TOTAL & & & & & & 675.80 \\
\hline $\begin{array}{l}\text { Nilai index total rata- } \\
\text { rata }\end{array}$ & & & & & & 84.48 \\
\hline
\end{tabular}

Terlihat pada tabel 7. bahwa indeks

rata-rata krateristik individual responden berada pada krakteristik individual responden berada pada kisaran tinggi secara umum pernyataan dalam variable materi $e$ learning menghasilkan angka indeks yang tinggi $(84,48 \%)$ sehingga semua pernyataan selanjutnya akan digunakan dalam pembuatan model persamaan regresi penelitian. Tingginya angka indeks ini juga mengindifikasikan bahwa variable desain materi e-learning memiliki pengaruh yang sangat dominan terhadap persepsi responden akan efektifitas program pelatihan yang mereka jalani bila dibandingkan dua variable bebas lainnya. 
Tabel 8.

Indeks Karakteristik Kinerja Pembelajaran Responden

\begin{tabular}{|c|c|c|c|c|c|c|}
\hline \multirow[t]{2}{*}{ Pernyataan $y^{1}$} & \multicolumn{5}{|c|}{ Frekuensi tiap skor (\%) } & \multirow[t]{2}{*}{ Nilai Index } \\
\hline & $\begin{array}{c}5 \\
(\mathrm{SS})\end{array}$ & $4(\mathrm{~S})$ & $3(\mathrm{R})$ & $\begin{array}{c}2 \\
(\mathrm{TS})\end{array}$ & 1 (STS) & \\
\hline Pernyataan 1 & 74 & 23 & 0 & 2 & 1 & 93.40 \\
\hline Pernyataan 2 & 52 & 46 & 0 & 2 & 0 & 89.60 \\
\hline Pernyataan 3 & 31 & 65 & 0 & 3 & 1 & 84.40 \\
\hline Pernyataan 4 & 30 & 45 & 0 & 24 & 1 & 75.80 \\
\hline Pernyataan 5 & 1 & 74 & 0 & 24 & 1 & 70.00 \\
\hline Pernyataan 6 & 22 & 73 & 0 & 4 & 1 & 82.20 \\
\hline Pernyataan 7 & 73 & 25 & 0 & 2 & $\overline{00}$ & 93.80 \\
\hline "Pernyataan 8 & $\overline{51}$ & 42 & 0 & 6 & 1 & 87.20 \\
\hline Total & & & & & & 6777.40 \\
\hline $\begin{array}{l}\text { Nilai Index Rata- } \\
\text { rata }\end{array}$ & & & & & & 83.93 \\
\hline
\end{tabular}

$$
\text { sumber : data diolah }
$$

Terlihat pada tabel 8. bahwa indeks

rata-rata karateristik individual responden berada pada kisaran tinggi $(83,93 \%)$. Secara umum, sumua pernyataan pada variable bebas kinerja pembelajaran menghasilkan angka indeks yang tinggi, hal ini mengindikasikan karateristik individual dan desain materi pelatihan yang sudah cukup memadai sehingga para peserta program mampu mengikuti alur pelatihan secara runtut dari awal bab, kuis di tiap bab atau bagian khusus yang memerlukan pemahaman lebih dalam, serta kuis pada akhir bab. Tingginya angka indeks pada variabel ini menunjukan tingkat keberhasilah program e-learning sekaligus juga mengidentifikasikan budaya perusahaan yang sebenarnya telah siap menerima perlatihan yang sifatnya non konvensioanal, jadi secara kualitatif dapat dibuktikan bahwa karakteristik individual BSS engineer, karakteristik organisasi telkomsel serta desain e-learning yang dibuat oleh manenjemen telah mampu menghasilkan keluaran yang cukup baik, bila dilihat dari kinerja pembelajaran yang dihasilkan. Lebih jauh lagi dapat penulis simpulkan bahwa sebagai suatu organisasi, maka PT telkomsel 
telah siap untuk melaksanakan jenis pelatihan jarak jauh secara online.

Tabel 9.

Indeks Karakteristik Kinerja Transfer Pengetahuan Responden

\begin{tabular}{|c|c|c|c|c|c|c|}
\hline \multirow[t]{2}{*}{ Pernyataan $y_{2}$} & \multicolumn{5}{|c|}{ Frekuensi tiap skor (\%) } & \multirow{2}{*}{$\begin{array}{l}\text { Nilai } \\
\text { Index }\end{array}$} \\
\hline & \begin{tabular}{l|l||}
5 \\
(SS
\end{tabular} & $\begin{array}{c}4 \\
\text { (S) }\end{array}$ & $\begin{array}{c}3 \\
(\mathrm{R})\end{array}$ & 2 (TS) & 1 (STS) & \\
\hline$\overline{\text { Pernyataan } 1}$ & 74 & 23 & 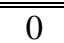 & 2 & 1 & 93.40 \\
\hline Pernyataan 2 & $\overline{552}$ & 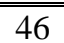 & 0 & $\overline{22}$ & $\overline{00}$ & 89.60 \\
\hline Pernyataaan 3 & 31 & 65 & 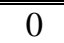 & 3 & $\overline{1}$ & 84.40 \\
\hline Pernyataan 4 & 30 & 45 & 0 & 24 & 1 & 75.80 \\
\hline Pernyataan 5 & 1 & 74 & 0 & 24 & 1 & 70.00 \\
\hline Pernyataaan 6 & 22 & $\overline{773}$ & $\overline{00}$ & $\overline{44}$ & $\overline{11}$ & 82.20 \\
\hline Pernyataan 7 & 73 & 25 & 0 & 2 & 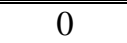 & 93.80 \\
\hline Pernyataan 8 & 51 & 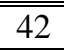 & 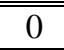 & $\bar{~} 6$ & 1 & 87.20 \\
\hline Total & & & & & & 2676.40 \\
\hline $\begin{array}{l}\text { Nilai index total rata } \\
\text { rata }\end{array}$ & & & & & & 84.55 \\
\hline
\end{tabular}

Terlihat tabel 9. bahwa indeks rata-

rata karakteristik individual responden

berada pada kisaran tinggi $(84,55 \%)$. Pada

variabel terikat kinerja transfer pengetahuan,

terlihat bahwa semua pernyataan direspon

positif dan menghasilkan angka indeks yang

tinggi. Hal ini mengindikasikan bahwa

program e-learning yang diimplementasikan

oleh PT Telkomsel terhadap BSS engineer

nya cukup berhasil di lihat dari adanya

persepsi responden mengenai adanya

peningkatan pengetahuan teoritis dan praktis yang didapatkan setelah program

berlangsung.

\subsection{Analisis Hasil Uji Kolerasi}

\subsubsection{Analisis Hipotesis 1}

Analisis hipotesis 1 : karateristik individu memperngaruhi efektifitas $e$ learning secara signifikan variable yang dikorelasikan adalah varialbel karakteristik indvidu $\left(X_{1}\right)$ terhadap variable terikat kinerja pembelajaran $\left(y_{1}\right)$ dan tingkat kinerja tranfers pengetahuan $\left(y_{2}\right)$. 
a. Kolerasi antara $x_{1}$ dan $y_{1}$

Keluaran program SPSS menghasilkan koefisien kolerasi $\mathrm{r}=0.438$. dari tabel nilai $\mathrm{r}$ product moment, untuk $\mathrm{n}=100$ dan taraf signifikasi $1 \%$ didapatkan $r_{\text {tabel }}=0.256=$ harga $r_{\text {hitung }}>r_{\text {tabel }}$ sehingga dapat dikatakan bahwa hipotesis diterima. Dengan demikian karakteristik individu yang diteliti sebagai sampel dalam penelitian ini berkolerasi positif dan signifikan terhadap efektifitas e-learning dalam definisinya sebagai kinerja pembelajaran. Hasil yang signifikan pada taraf signifikan $1 \%$ berarti sampel penelitian dapat digeneralisasikan pada populasi BSS engineer di PT Telkomsel dengan margin kesalahan hanya 1\%. Sejauhmana pengaruh karateristik individual terhadap kinerja pembelajaran dapat diketahui melalui koefisien determinasi $R^{2}=19.18 \%$ yang artinya $19.18 \%$ dari kinerja pembelajaran ditentukan oleh karakteristik individual peserta e-learning.
b.Kolerasi antara $x_{1}$ dan $y_{2}$

Keluaran program SPSS menghasilkan koefesien kolerasi $\mathrm{r}=0.651$. Dari tabel nilai $r$ product moment, untuk $n=100$ dan taraf signifikansi $1 \%$ didapatkan $r_{\text {tabel }}=$ 0.256. Harga $r_{\text {hitung }}>r_{\text {tabel }}$ sehingga dapat dikatakan bahwa hipotesis diterima. Dengan demikian karateristik individu yang diteliti sebagai sampel dalam penelitian ini berkorelasi positif dan signifikan terhadap efektifitas e-learning dalam definisinya sebagai kinerja tranfer pengetahuan. Hasil yang signifikan pada taraf signifikan $1 \%$ berarti sampel penelitian dapat digeneralisasikan pada populasi BSS engineer di PT Telkomsel dengan margin kesalahan hanya $1 \%$. Sejauh mana karateristik individual terhadap kinerja transfer pengetahuan dapat diketahui melalui koefisien determinasi $\mathrm{R}^{2}=42.38 \%$ yang artinya $42.38 \%$ dari kinerja transfers pengetahuan 
ditentukan oleh karakteristik individual peserta e-learning.

Dilihat dari model penelitian dimana variable $x_{1}$ memiliki tiga indikator yaitu kemauan pribadi, kemapuan menggunakan computer serta tingkat hasil belajar yang diharapkan, maka berberapa pernyataan dari angket menghasilkan respon positif.

Pernyataan dalam variable $x_{1}$ yang paling banyak mengahasilkan respon negative adalah pertanyaan 7 dan 8 yang termasuk dalam indikator kampuan diri, sub indikator lokus kendali diri. Dilihat dari lokasi kerja responden yang memberikan respon negatif terhadap kedua pernyataan tersebut, didapatkan fakta bahwa sebagian besar adalah BSS engineer yang berlokasi kerja remote area dimana waktu kerja mereka lebih panjang kerena hampir semua pekerjaan dilakukan secara mandiri yang menuntut penggunaan lebih dari tenaga, pikiran dan waktu mereka sehingga kekurangan waktu dan kurang fokus untuk mengetahui program e-learning secara konsisten. Disimpulkan bahwa hipotesis adanya hubungan erat serta bersifat kausalitas antara krateristik peserta program e-learning terhadap kinerja pembelajaaran $\left(\mathrm{y}_{1}\right)$ yang dihasilkan adalah benar terbukti.

\subsubsection{Analisis Hipotesis 2}

Analisis hipotesis 2 : karakteristik organisasi mempengaruhi efektifitas elearning secara signinfikan. variable yang dikoleraasikan adalah variable krateristik organisasi $\left(x_{2}\right)$ terhadap variable tingkat kinerja pembelajaraan $\left(y_{1}\right)$ dan kinerja transfer pengetahuan $\left(y_{2}\right)$.

a. Kolerasi antara $x_{2}$ dan $y_{1}$

Keluaran program SPSS menghasilkan koefisien kolerasi $\mathrm{r}=0.689$. daro table nilai $\mathrm{r}$ product moment, untuk $\mathrm{n}=100$ dan taraf signifikan $1 \%$ didapatkan $\mathrm{r}_{\text {tabel }}=$ 0.256 harga $r_{\text {hitung }}>r_{\text {tabel }}$ sehingga dapat dikatakan bahawa hipotesis diterima. Dengan demikian karateristik 
organisasional yang diteliti dalam penelitian berkolerasi positif dan signifikan terhadap efektifitas e-learning dalam definisinya sebagai kinerja pembelajaran. Hasil yang signifikan pada taraf signifikan $1 \%$ berarti sample penelitian dapat digeneralisasikan pada populasi BSS engineer di PT Telkomsel dengan margin kesalahan hanya $1 \%$. Sejauhmana pengaruh karakteristik organisasional terhadap kinerja pembelajaran dapat diketahui melalui koefisien determinasi $R^{2}=47.5 \%$ yang artinya $47.5 \%$ dari kinerja pembelajaran ditentukan oleh karakteristik organisasional dari perusahaan penyelenggara program $e$ learning.

b. Kolerasi antara $x_{2}$ dan $y_{2}$

Keluaran program SPSS menghasilkan koefisien kolerasi $\mathrm{r}=0.766$. dari table nilai $\mathrm{r}$ product moment, untuk $\mathrm{n}=100$ dan taraf signifikan $1 \%$ didapatkan $r_{\text {tabel }}=0.256$ harga $\mathrm{r}_{\text {hitung }}>\mathrm{r}_{\text {tabel }}$ sehingga dapat dikatakan bahwa hipotesis diterima. Dengan demikian karakteristik organisasi yan diteliti dalam penelitian berkolerasi positif dan signifikan terhadap efektifitas e-learning dalam definisinya sebagai kinerja transfer pengetahuan. Hasil yang signifikan pada taraf signifikan $1 \%$ berarti sampel penelitian dapat digeneralisasikan pada populasi BSS engineer di PT Telkomsel dengan margin kesalahan hanya $1 \%$. Sejauh mana pengaruh karakteristik organisasional terhadap kinerja transfer pengetahuan dapat diketahui melalui koefisien determinasi $R^{2}=58.7 \%$ yang artinya $58.7 \%$ dari kinerja transfer pengetahuan ditentukan oleh karakteristik organisasional dari perusahaan penyelenggara program e-learning.

Dilihat dua indikator yaitu desain strategi instruksional dan dukungan luar dalam hal ini adalah dukungan teknis dari organisasi dan rekan sekerja, maka berberapa pertanyaan angket mengahasilkan positif . 
Pernyataan dalam variable $x_{2}$ yang paling banyak menghasilkan respon negatif adalah 4 dan 5 yang termasuk dalam indikator desain strategi instruksional sub indikator strategi manejemen pelatihan. Respon negatif paling terlihat pada pernyataan yang menginformasikan apakah perusaaan memberikan waktu khusus bagi BSS engineer untuk mengikuti program elearning tanpa harus diganggu oleh pekerjaan penanganan gangguan.

Pada model penelitian dari Lowe et all ( A theory of effective computer-based instruction for adults) dinyatakan bahwa strategi manajemen pelatihan berhubungan dengan peraturan pelaksaaan pelatihan yang meliputi pengaturan jadual, pengaturan sarana teknis serta pengaturan serangkaian intruksi selama pelatihan berlangsung. Pengaturan instruksi ini dimaksudkan agar setiap peserta mendapatkan status terkini dalam setiap tahapan materi yang disajikan hingga pemberian skor test akhir dan pembuatan sertifikat online. Kondisi negatif yang diberiksn oleh lingkungan organisasi terhadap peserta secara pasti akan menghasilkan respon negatif dari peserta karena peserta akan sangat terganggu oleh pekerjaan rutin sehingga tahapan-tahapan program yang telah disusun sedemikan rupa tidak mampu menghasilkan tingkat pemahaman yang optimal bagi peserta. Prinsip dasar program e-learning yang mensyaratkan instruksi secara berurut disamping mampu mengakomodaasi fleksibilitas kemampuan peserta dalam hal ini kurang diabaikan oleh organisasi yang diteliti, dan hasilnya adalah respon negatif peserta dalam penyataan angket.

Secara keseluruhan, respon dari sempel pada pertanyaan-pertanyaan dalam variable $x_{2}$ adalah positif dan menghasilkan resultan yang positif juga. Hasil pengelolahan data menunjukan hipotesis "karakteristik organisasional memperngaruhi 
efektifitas e-learning secara signifikan “ telah terbukti.

\subsubsection{Analisis Hipotesis 3}

Analisis Hipotesis 3: karakteristik materi e-learning mempengaruhi efektifitas e-learning mempengaruhi efektifitas $e$ learning secara signifikan. Variabel yang dikolerasikan adalah variable karakteristik materi e-learning $\left(x_{3}\right)$ terhadap variabel terkait kinerja pembelajaran $\left(y_{1}\right)$ dan kinerja tranfers pengetahuan $\left(y_{2}\right)$.

a. Kolerasi antara $x_{3}$ dan $y_{1}$

Keluaran program SPSS menghasilkan $r=$ 0.961. dari table nilai $\mathrm{r}$ product moment, untuk $\mathrm{n}=100$ dan taraf signifikansi $1 \%$ didapatkan $r_{\text {tabel }}=0.256$ harga $r_{\text {hitung }}>r_{\text {tabel }}$ sehingga dapat dikatakan bahwa hipotesis diterima. Dengan demikian karakteristik organisasi yang diteliti dalam penelitian ini berkorelasi positif dan signifikan terhadap efektifitas e-learning dalam definisinya sebagai kinerja pembelajaran. Hasil yang signifikan pada taraf signifikansi $1 \%$ berarti sampel penelitian dapat digeneralisasikan pada populasi BSS engineer di PT Telkomsel dengan margin kesalahan $1 \%$. Sejauh mana pengaruh karakteristik materi e-learning terhadap kinerja pembelajaran dapat diketahui melalui koefisien determinasi $R^{2}=92.35 \%$ yang artinya $92.35 \%$ dari kinerja pembelajaran ditentukan oleh karateristik materi e-learning dari perusahaan penyelengara program e-learning.

b. Kolerasi antara $x_{3}$ dan $y_{2}$

Keluarkan program SPSS menghasilkan $r$ $=0.926$. Dari tabel nilai $\mathrm{r}$ product moment, untuk $\mathrm{n}=100$ dan taraf signifikansi $1 \%$ didapatkan $r_{\text {tabel }}=0.256$ harga $r_{\text {hitung }}>r_{\text {tabel }}$ sehingga dapat dikatakan bahwa hipotesis diterima. Dengan demikian karakteristik organisasi yang diteliti dalam penelitian ini berkorelasi positif dan signifikan terhadap efektifitas 
e-learning dalam definisinya sebagai kinerja transfer pengetahuan. Hasil yang signifikan pada taraf signifikan $1 \%$ berarti sampel penelitian dapat digeneralisasikan pada populasi engineer BSS di PT Telkomsel dengan margin kesalahan hanya 1\%. Sejauhmana pengaruh karakteristik materi e-learning terhadap kinerja transfer pengetahuan dapat diketahui melalui koefisien determinasi $R^{2}=85.75 \%$ yang artinya $85.75 \%$ dari kinerja transfer pengetahuan ditentukan oleh karateristik materi e-learning dari perusahaan penyelengara program e-learning.

Berbeda dengan dua variable lainnya, hampir keseluruhan pernyataan pada variable $x_{3}$ menghasilkan respon positif. Dapat dikatakan bahwa seluruh sampel BSS engineer menganggap desain materi $e$ learning yang mereka ikuti sudah cukup memadai dan sesuai dengan harapan. Beberapa jawaban negatif didapatkan dari responden yang ternyata kurang memiliki akses terhadap program ini akibat keterbatasan prasarana misalnya jaringan data yang kurang handal dan lokasi kerja yang jauh. Responden jenis ini biasanya adalah BSS engineer yang mendapat penugasan remote area. Karena sebaran dan jumlah mereka yang kecil dibandingkan lokasi kerja BSS pada umumnya, maka penulis mengasumsikan respon negatif mereka sebagai akibat dari kondisi lingkungan kerja dan bukan dari desain materi e-lerning itu sendiri.

Secara keseluruhan, respon dari sampel pada pernyataan-pernyataan dalam variable $x_{3}$ adalah positif dan menghasilkan resultan yang positif juga. Hasil pengelolahan data menunjukan hipotesis "kareteristik materi e-learning mempengaruhi efektifitas e-learning secara signifikan" telah terbukti. 


\subsection{Analisis Uji Regresi}

Regresi yang digunakan dalam pengelolahan data penelitian dalam pengelolahan data pada penelitian ini adalah regresi linear multivariate. Ketiga variable bebas $: x_{1}, x_{2}, x_{3}$ akan dihubungkan dengan variable terkait $y_{1}, y_{2}$ melalui suatu perssamaan regresi linear. Karena variable bebas: efektifitas pelaksaaan e-learning dengan efektifitas program e-learning itu sendiri.

\subsubsection{Regrsi $x_{1}, x_{2}, x_{3}$ terhadap $y_{1}$}

Dari pengolahan menggunakan perangkat lunak SPSS 17.0 pada bab sebelumnya didapatkan hasil sebagai berikut:

Tabel 10

Model Summary Regresi $x_{1}, x_{2}, x_{3}$ terhadap $y_{1}$

\begin{tabular}{|c|c|c|c|c|c|c|c|c|c|}
\hline \multirow[t]{2}{*}{ Model } & \multirow[t]{2}{*}{$\mathrm{R}$} & \multirow{2}{*}{$\begin{array}{c}\mathrm{R} \\
\text { suquare }\end{array}$} & \multirow{2}{*}{$\begin{array}{l}\text { Adjusted } \\
\text { R square }\end{array}$} & \multirow{2}{*}{$\begin{array}{l}\text { Std. error } \\
\text { of } \\
\text { thestimate }\end{array}$} & \multicolumn{5}{|c|}{ Change statistics } \\
\hline & & & & & $\begin{array}{c}\mathrm{R} \\
\text { square } \\
\text { change }\end{array}$ & $\begin{array}{c}\mathrm{F} \\
\text { change }\end{array}$ & $\overline{\text { Df1 }}$ & $\overline{\text { Df2 }}$ & $\begin{array}{c}\text { Sig.F } \\
\text { Change }\end{array}$ \\
\hline 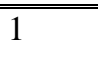 & $.965^{\alpha}$ & .931 & 9929 & ב.21617 & .931 & 434.813 & 3 & 96 & .000 \\
\hline
\end{tabular}

a.Predictors : (constant), karakteristik Materi E-learning, karakteristik individual, karateristik Organisasi

b. Dependent variable : kinerja pembelajaran

Tabel 11.

Koefisien Regresi $x_{1}, x_{2}, x_{3}$ terhadap $y_{1}$

\begin{tabular}{|c|c|c|c|c|c|}
\hline \multirow[t]{2}{*}{ Model } & \multicolumn{2}{|c|}{$\begin{array}{c}\text { Unstandardized } \\
\text { Coefficients } \\
\end{array}$} & \multirow{2}{*}{$\begin{array}{c}\text { Standardize } \\
\text { Coefficients } \\
\text { beta }\end{array}$} & \multirow[t]{2}{*}{$\mathbf{t}$} & \multirow[t]{2}{*}{ Sig. } \\
\hline & $\mathrm{B}$ & Std. Error & & & \\
\hline 1 (constant) & 435 & 255 & & 1.710 & .091 \\
\hline Karakteristik individual & 296 & 090 & -130 & -13.285 & .001 \\
\hline Karateristik organisasi & 344 & 124 & 145 & 2.768 & .007 \\
\hline $\begin{array}{l}\text { Karateristik materi E- } \\
\text { learning }\end{array}$ & 901 & 040 & 902 & 22.704 & .000 \\
\hline
\end{tabular}

a dependent variable : kinerja pembelajaran

Tabel 12.

ANOVA Regresi $\mathrm{X}_{1}, \mathrm{X}_{2}, \mathrm{X}_{3}$ terhadap $\mathrm{Y}_{1}$

\begin{tabular}{||l||l||l||l||l||r||}
\hline Model & $\begin{array}{l}\text { Sum of } \\
\text { squares }\end{array}$ & df & $\begin{array}{l}\text { Mean } \\
\text { square }\end{array}$ & F & Sig. \\
\hline \hline 1 & 60.956 & 3 & 20.319 & 434.813 & .000 \\
Regression & 4.486 & 96 & .047 & & \\
$\quad \begin{array}{l}\text { Residual } \\
\text { Total }\end{array}$ & 65.442 & 99 & & & \\
\hline
\end{tabular}


Hasil uji-t untuk ketiga variable pada tingkat signifikan $1 \%$ berdasarkan tabel 10. menunjukan pengaruh karateristk individual, karateristik organisasional dan karateristik materi e-learning terhadap kinerja pembelajaran dapat dibuktikan dengan tingkat kepercayaan $99 \%$ kolerasi ketiga variable bebas secara bersama-sama adalah sebesar 0.965 dengan tingkat signifikan pada uji-F sebesar 0.000 mendekati $0 \%$ yang artinya sangat goodness of-fit terjadi.dengan tingkat signifikan sedemikian dapan disimpulkan bahwa regresi diatas layak untuk menjelaskam hubungna kuasalitas antara ketiga variable bebas terhadap variable terikat.diregresikan terhadap kenerja pembelajaran.

Pada persamaan regresi yang dihasilkan.Terdapat suatu hubungann negatif yang ditandai oleh koefisien bernilai negatif pada variable karateriistik individu.Koefisien negatif pada variable karateristik individual. Koefisien negatif ini tidak menandakan andanya hubungan negatif antara variable karateristik individual terhadap kinerja pembelajaran, melainkan hanya respresentasi matematis sebagai akibat digunakan analisi regresi linear. Kenyataan bahwa didapatkan kolerasi person yang signifikam antara karateristik individual terhadap kinerja pembelajaran serta dihasilkan koefisien regeresi sebesar 0.965 pada tingkat signifikan semua variable mendekati 0.00 adalah bukti adanya kualitas yang signifikan antara semua variable bebas yang diregresikan terhadap kinerja pembelajaran.

\subsubsection{Regresi $x_{1}, x_{2}, x_{3}$ terhadap $y_{2}$}

Dari pengolahan menggunakan perangkat lunak SPSS 17.0 pada bab sebelumnya didapatkan hasil sebagai berikut: 
Tabel 13

Koefisien Regresi $\mathrm{X}_{1}, \mathrm{X}_{2}, \mathrm{X}_{3}$ terhadap $\mathrm{Y}_{2}$

\begin{tabular}{|c|c|c|c|c|c|}
\hline \multirow[t]{2}{*}{ Model } & \multicolumn{2}{|c|}{$\begin{array}{l}\text { Unstandardized } \\
\text { Coefficients }\end{array}$} & $\begin{array}{l}\text { Standardize } \\
\text { Coefficients }\end{array}$ & \multirow[t]{2}{*}{$\mathrm{t}$} & \multirow[t]{2}{*}{ Sig. } \\
\hline & B & Std. Error & beta & & \\
\hline 1 (constant) & .408 & .209 & & 1.955 & .053 \\
\hline Karakteristik & .367 & .074 & -.237 & 4.974 & .000 \\
\hline individual & - & .102 & -031 & -497 & 621 \\
\hline Karateristik & .051 & .032 & .896 & 18.205 & .000 \\
\hline $\begin{array}{l}\text { organisasi } \\
\text { Karateristik } \\
\text { materi E- } \\
\text { learning }\end{array}$ & .592 & & & & \\
\hline
\end{tabular}

Tabel 14.

Summary Regresi $x_{1}, x_{2}, x_{3}$ terhadap $y_{2}$

\begin{tabular}{|c|c|c|c|c|c|c|c|c|c|}
\hline \multirow[t]{2}{*}{ Model } & \multirow[t]{2}{*}{$\mathrm{R}$} & \multirow{2}{*}{$\begin{array}{l}\mathrm{R} \\
\text { suquare }\end{array}$} & \multirow{2}{*}{$\begin{array}{l}\text { Adjusted } \\
\text { R square }\end{array}$} & \multirow{2}{*}{$\begin{array}{l}\text { Std. error } \\
\text { of } \\
\text { thestimate }\end{array}$} & \multicolumn{5}{|c|}{ Change statistics } \\
\hline & & & & & $\begin{array}{l}\text { R square } \\
\text { change }\end{array}$ & $\begin{array}{c}\mathrm{F} \\
\text { change }\end{array}$ & Df1 & Df2 & $\begin{array}{c}\text { Sig.F } \\
\text { Change }\end{array}$ \\
\hline 1 & $.949^{\alpha}$ & .901 & .898 & .17710 & 9.901 & 290.809 & 3 & 96 & 000 \\
\hline
\end{tabular}

a. Predictors : (Constant), Karakateristik Materi E-Learning, Karakteristik Individual, Karakteristik Organisasional

b. Dependent variable : kinerja transfer pengetahuan

Tabel 15.

ANOVA Regresi $x_{1}, x_{2}, x_{3}$ terhadap $y_{2}$

\begin{tabular}{|c|r|r||r||r|r||}
\hline Model & $\begin{array}{r}\text { Sum of } \\
\text { squares }\end{array}$ & \multicolumn{1}{|c|}{ df } & $\begin{array}{r}\text { Mean } \\
\text { square }\end{array}$ & F & Sig. \\
\hline \hline 1 & 27.362 & 3 & 9.121 & 290.809 & .000 \\
Regression & 3.011 & 96 & .031 & & \\
Residual & 30.373 & 99 & & & \\
Total & & & & & \\
\hline
\end{tabular}

$$
\mathrm{y}_{2}=0.408+0.367 x_{1}+0.051_{2}+0.592 x_{\text {a }}
$$

Berbeda dengan persamaan regresi

sebelumnya dimana hasil regresi

menunjukan kolerasi signifikan dari semua

variable bebas terhadap variable terkaitnya

maka pada persamaan kedua ini ternyata

karateristik organisasional hanya berkorelasi

positif terhadap kinerja transfer pengetahuan pada tingkat signifikan $62.1 \%$ dan harus dibuang dari model regresi. Walaupun secara keseluruhan terdapat hubungan kualitas yang signifikan antara ketiga variable bebas terhadap kinerja transfer pengetahuan yang ditandai dengan niali $r=0.949$ pada tingkat signifikan sig $=0.000$ tetapi secara parsial, 
dalam persamaan regresi yang dihasilkan

revisi model harus dilakukan untuk ternyata $x_{2}$ kurang memiliki pengaruh mendapatkan persamaan regresi tanpa dibandingkan kedua variable bebas lainya melibatkan vaariabel karakteristik organisasional.

Tabel 16.

Revisi Model Regresi $x_{1}, x_{2}, x_{3}$ terhadap $y_{2}$

\begin{tabular}{|c|c|c|c|c|c|c|c|c|c|}
\hline \multirow[t]{2}{*}{ Model } & \multirow[t]{2}{*}{$\mathrm{R}$} & \multirow{2}{*}{$\begin{array}{l}\mathrm{R} \\
\text { suquare }\end{array}$} & \multirow{2}{*}{$\begin{array}{l}\text { Adjusted } \\
\text { R square }\end{array}$} & \multirow{2}{*}{$\begin{array}{l}\text { Std. error } \\
\text { of } \\
\text { thestimate }\end{array}$} & \multicolumn{5}{|c|}{ Change statistics } \\
\hline & & & & & $\begin{array}{l}\mathrm{R} \\
\text { square } \\
\text { change }\end{array}$ & $\begin{array}{l}\text { F } \\
\text { change }\end{array}$ & Df1 & Df2 & $\begin{array}{l}\text { Sig.F } \\
\text { Change }\end{array}$ \\
\hline 1 & $.949^{a}$ & .901 & .899 & .17641 & .901 & 439.504 & 2 & 97 & .000 \\
\hline
\end{tabular}

a.Predictors : (constant), karakteristik Materi E-learning, karakteristik individual

b. Dependent variable : kinerja transfer pengetahuan

Tabel 17.

Revisi ANOVA Regresi $x_{1}, x_{2}, x_{3}$ terhadap $y_{2}$

\begin{tabular}{|l||l||l||l||l||l||}
\hline \hline Model & $\begin{array}{l}\text { Sum of } \\
\text { squares }\end{array}$ & df & $\begin{array}{l}\text { Mean } \\
\text { square }\end{array}$ & F & Sig. \\
\hline \hline 1 Regression & 27.354 & 3 & 13.677 & 439.504 & .000 \\
Residual & 3.019 & 97 & .031 & & \\
Total & 30.373 & 99 & & & \\
\hline
\end{tabular}

a.Predictors : (constant), karakteristik Materi E-learning, karakteristik individual

b. Dependent variable : kinerja transfer pengetahuan

Tabel 18.

Koefisien Revisi Model regresi $\mathrm{X}_{1}, \mathrm{X}_{2}, \mathrm{X}_{3}$ terhadap $\mathrm{Y}_{2}$

\begin{tabular}{|c|c|c|c|c|c|}
\hline \multirow{2}{*}{ Model } & \multicolumn{2}{|c|}{$\begin{array}{l}\text { Unstandardized } \\
\text { Coefficients }\end{array}$} & \multirow{2}{*}{$\begin{array}{r}\text { Standardize } \\
\text { Coefficients } \\
\text { beta }\end{array}$} & \multirow{2}{*}{$\mathrm{t}$} & \multirow{2}{*}{ Sig. } \\
\hline & $\mathrm{B}$ & $\begin{array}{c}\text { Std. } \\
\text { Error }\end{array}$ & & & \\
\hline $\begin{array}{l}\text { (constant) } \\
\text { Karakteristik } \\
\text { individual } \\
\text { Karateristik } \\
\text { materi E- } \\
\text { learning }\end{array}$ & $\begin{array}{l}.389 \\
.341 \\
.508\end{array}$ & $\begin{array}{l}.204 \\
.503 \\
.023\end{array}$ & $\begin{array}{l}.220 \\
.853\end{array}$ & $\begin{array}{l}1.904 \\
6.485 \\
25.12 \\
7\end{array}$ & $\begin{array}{l}.060 \\
.000 \\
.000\end{array}$ \\
\hline
\end{tabular}

Pada persamaan revisi ini, sebesar 0.000 yang artinya korelasi antara didapatkan tingkat signifikan $x_{1}$ dan $x_{2}$ kedua variable tersebut terhadap kinerja 
transfer pengetahuan sangat erat. Uji kelayakan model dapat dilakukan dengan melihat nilai $r=0.949$ dengan sig $=0.000$ yang menunjukan goodness of-fit model regresi yang digunakan. untuk mengetahui perbedaan tingkat kolerasi antara variable bebas dengan variabel terikatnya secara bersamaan sesuai dengan regresi yang dihasilkan pada kedua persamaan diatas. Penulis menganalisisnya dari jawaban responden pada angket yang diberikan terutama pada bagian variabel karateristik organisasi. Dari jawaban angket terlihat bahwa pernyataan yang sering diberi skor negative (skor- $<3$ ) pada variable $x_{2}$ adalah pernyataan bahwa peserta e-learning tidak disibukan oleh pekerjaan rutinnya seperti penanganan gangguan selama mengikuti program.

Berdasarkan model penelitian yang penulis gunakan serta berberapa pendapat peneliti di bidang pelatihan sumber daya manusia, penulis mengambil kesimpulan bahwa memang ada hubungan signifikan antara dukungan organisasi pada efektifitas pelaksanaan program pelatihan online yang dalam pelatihan ini ternyata ditemukan fakta bahwa organisasi yang diteliti ini belum meberikan dukungan yang optimal dari sisi penyediaan waktu khusus bagi BSS engineer untuk mengikuti pelatihan online. Temuan bahwa karateristik organisasional tidak memiliki korelasi yang menguatkan hipotesis bahwa ada hubungan yang signifikan dan bersifat kuasalitas antara karateristik organisional terhadap efektifitas pelaksanaan program pelatihan oline melalui $e$-lerning.

\section{KESIMPULAN DAN SARAN}

\subsection{Kesimpulan}

Kesimpulan dari penelitian yang telah dilakukan adalah sebagai berikut :

a. Terdapat kolerasi signifikan dan bersifat kausalitas antara karateristik individual peserta program e-learning terhadap 
tingkat efektiftas pelaksanaan program $e$ learning. Kemampuan rata-rata BSS engineer akan teknologi komunikasi yang cukup tinggi ditambah dengan kemampuan kognitif yang memadai merupakan indikator efektiftas program e-learning yang mereka-dapatkan.

b.Terdapat kolerasi yang signifikan dan bersifat kuaslitas antara karateristik organisasional penyelengara program $e$ learning terhadap. tingkat efektifitas pelaksanaan program e-learning. Dukungan perusahaan pada peserta berupa kemudahan proses registrasi online didukung adanya jaringan komputer yang memadai merupakan indikator dari karakteristik organisasional yang mendukung efektifitas pelaksanaan $e$ learning bagi BSS engineer dilikungan PT Telkomsel.

c. Terdapat kolerasi yang signifikan dan bersifat kausalitas antara karakteristik materi e-learning terhadap tingkat efektifitas pelaksanaan program elearning, adapun desain materi e-learning sendiri ternyata memiliki porsi terbesar yang mempengaruhi efektifitas e-learning yang dibuktikan dengan lebih tingginya korelasi persial variabel ini terhadap kinerja pembelajaran dan kinerja transfers pengetahuan dibandingkan dengan korelasi kedua variabel-bebas-lainnya.

Di sisi lainya, pada penelitian ini juga didapatkan fakta bahwa tidak diberikannya waktu khusus bagi BSS engineer yang inigin melaksanakan pelatihan online tanpa diganggu tugas rutinnya ini merupakan indikator dari karakteristik organisaional yang kontra-produktif terhadap efektifitas pelatihan. Indikator yang kontraproduktif ini lebih besar pengaruhnya terhadap kinerja transfer pengetahuan dibandingkan pengaruh pada kinerja pembelajaran. 


\subsection{Saran}

Saran-saran yang dapat diberikan dari hasil penelitian ini adalah sebagai berikut :

a. Organisasi yang menjadi objek penelitian harus memberikan waktu khusus bagi BSS engineer untuk mengikuti program $e$ learning tanpa diganggu tugas rutinnya dalam penanganan gangguan jaringan.

b. Komitmen organisasi pada implementasi program pelatihan online harus ditingkatkan dengan memberi semacam sanksi administratif bagi karyawan yang tidak mengikuti program pelatihan online untuk meningkatkan motivasi belajar.

c.Perlu dilakukannya penelitian lanjutan dengan mengukur kinerja mengingat pada penelitian ini adanya peningkatan kemampuan didapatkan hanya melalui persepsi responden tanpa pengukuran perubahan perilaku yang terjadi.

d.Selain pengukuran peningkatan kinerja setelah pelaksanaan pelatihan,perlu juga dibuat suatu kelompok pengendali yang terdiri dari berberapa BSS engineer yang tidak mendapatkan pelatihan untuk kemudian dibandingkan kinerjanya dengan engineer lain yang mengikuti program $e$ learning agar efektifitas pelatihanya dapat terlihat jelas. 


\section{DAFTAR PUSTAKA}

Alvarez, Salas dan Garofano, 2010 An Integrated Model of Training Evaluation and Effectiveness, University of Central Florida. Sage Publication.

Attwood, Dimmock, 2010. Manajemen Personalia, Penerbit ITB Bandung.

Augusty, Fedinand Prof, 2006. Metode Penelitian Manajemen, BP UNDIP.

Dimmock. 2004. Optimizing E-learning: research-Based Guidelines for Learner-Controlledn Training. Human Resource Management, Wiley Periodicals Inc.

Hanum, Numiek Sulistyo,Februari 2013. "Keefektifan E-learning Sebagai Media Pembelajaran", Jurnal Pendidikan Vokasi, Vol. 3, Nomor 1.

Hidayat, Ali, 2011. Pengaruh Penggunaan E-learning Terhadap Motivasi dan Efektifites Pembelajaran Fisika Bagi Siswa SMA, Konferensi Nasional Sistem Informasi, Jakarta.

Lowe, J.S \& Holton, E.F, June 2005. A Theory of Effective Computer-Based Instruction for Adults. Human Resource Development Review, ABI/INFORM Research.

Mondy,Wayne. R,.2008.Manajemen Sumber Daya Manusia, Penerbit Erlangga.

Nu'man, Ahmad Zanin, September 2014. "Efektifitas Penerapan E-learning Model Edmodo Dalam Pembelajaran Pendidikan Agama Islam terhadap Hasil Belajar Siswa", Duta.com, ISSN: 20869436 Volume 7, Nomor 1 .

Riduan, 2010. Skala Pengukuran Variabel-variabel Penelitian, CV. Alfabeta, Bandung.

Sahijwani, Sivalingam, Roza, 2009. E-learning in South East Asia, Proceeding of the Second International Conference on elearning for Knowledge-Based Society, August 4-7, 2005, Bangkok, Thailand, The Cape Group.

Sugiyono, Prof, 2007. Metode Penelitian Bisnis. Alfabeta, Bandung.

Suryani dan Hendryadi. 2015. Metode Riset Kuantitatif Teori dan Aplikasi pada Penelitian Bidang Manajemen dan Ekonomi Islam, Prenadamedi Group.

Williams, SW. 2000. "Towards a framework for Teaching and Learning in An Online Environment : A review of the literature in K.P Kunchinke (Ed)". Proceeding of the Academy of Human Resource Development Annual Confference, Baton Rouge, LA. 